\title{
Stories from the field: women's networking as gender capital in entrepreneurial ecosystems
}

\author{
Maura McAdam • Richard T. Harrison • \\ Claire M. Leitch
}

Accepted: 15 December 2017 / Published online: 13 February 2018

(C) The Author(s) 2018. This article is an open access publication

\begin{abstract}
Women are under-represented in successful entrepreneurial ecosystems and the creation of womenonly entrepreneurial networks has been a widespread policy response. We examine the entrepreneurial ecosystem construct and suggest that it, and the role networks play in entrepreneurial ecosystems, can be analysed in terms of Bourdieu's socio-analysis as field, habitus and capital. Specifically, we develop the notion of gender capital as the skill set associated with femininity or from simply being recognized as feminine. We apply this to the development of women's entrepreneurial networks as a gender capital enhancing initiative. Using data from qualitative interviews with network coordinators and women entrepreneurs, we reflect on the extent to which formally established women-only networks generate gender capital for their members and improve their ability to participate in the entrepreneurial ecosystem. The paper concludes by drawing out the implications of our analysis for theory, entrepreneurial practice and economic development policy.
\end{abstract}

M. McAdam

DCU Business School, Dublin City University, Dublin 9, Ireland

R. T. Harrison $(\bowtie)$

Centre for Strategic Leadership, Centre for Entrepreneurship

Research, University of Edinburgh Business School, 29

Buccleuch Place, Edinburgh, Scotland EH8 9JS, UK

e-mail: r.harrison@ed.ac.uk

C. M. Leitch

Department of Leadership and Management, Lancaster University Management School, Lancaster University, Bailrigg, Lancaster, England LA1 4YX, UK
Keywords Entrepreneurial ecosystems · Networks · Bourdieu $\cdot$ Habitus $\cdot$ Field $\cdot$ Gender capital $\cdot$ Women entrepreneurs

JEL Classification L26 J16 $\cdot$ B54

\section{Introduction}

A healthy inclusive entrepreneurial ecosystem requires four domain conditions to become established and develop: density, as in the number and proportion of individuals engaged in entrepreneurship; fluidity, including population flux, labour market change and firm growth; connectivity, reflected in the existence of deal making and other networks; and diversity of opportunity (Stangeler and Bell-Masterson 2015). In all four domains, women's entrepreneurial activity is underrepresented: the relative share of women in and entering into entrepreneurship is lower than of men (Motoyama et al. 2014); women are leaving employment in STEM-based industries, due to a hostile environment, gender bias and glass wall/ceiling effects, reducing their potential entrepreneurial contribution (Hewlett 2014); where networks exist, they are not gender inclusive and women do not participate (Watkins 2015; Boyde 2017); and women are significantly under-represented in what is still a highly masculinized domain (Ahl 2006). From both a liberal feminist standpoint, which in the broader tradition of Post-Enlightenment liberalism argues that women are equal to men and entitled to equal legal and political standing and social and economic opportunity 
(Graham 1994), and an entrepreneurial ecosystems perspective, it has been argued that access to networks can improve women's contribution to and participation in entrepreneurial ecosystems. We put this argument under scrutiny, drawing on Bourdieu's (2005) theory of embodied practice, and in particular on his concepts of field, habitus and capital, which has received increasing attention in entrepreneurship (Spigel 2015). While this is most immediately relevant to connectivity as a domain condition for the development of entrepreneurial ecosystems, the development of effective networks has also the potential to affect the other domain conditions, by improving the quantity of entrepreneurial activity (density), enhancing entrepreneurial activity (which will support fluidity) and, in the case of female entrepreneurship in particular, legitimise entrepreneurship as a career choice (diversity of opportunity).

Our starting point is that a persistent gender bias exists in both entrepreneurship discourse and economic development policy (Ahl 2006; Ahl and Nelson 2015). This perpetuates hetero-normative assumptions that women are failed or reluctant entrepreneurial subjects, who have not been socialised appropriately to compete in a man's world and require 'fixing' by specific policy interventions to provide them with the tools and skills to do so (Ahl and Marlow 2012; Ely and Meyerson 2000). One such example has been the establishment of women-only networks by economic development agencies, as a catalyst to the development of an entrepreneurial culture in an entrepreneurial ecosystem (Fritsch 2011). This is predicated on a positive view of networks as sites of gender capital creation and accumulation designed to empower women and provide them with agency that has the potential to disrupt the status quo in entrepreneurial ecosystems (Huppatz 2012). However, on the basis of our analysis, we identify a tension between this view and the argument that these womenonly networks may perpetuate the ghettoization of women which limits their legitimacy as entrepreneurial actors (Feng 2015).

Our aim is to investigate the extent to which these formal women-only networks improve women's access to, and participation, in entrepreneurial ecosystems. We make four contributions in this paper. First, we deepen understanding of the concept of the entrepreneurial ecosystem, which is currently contested, lacking both a commonly agreed definition and generally accepted characterizations. Second, we integrate the networks and entrepreneurial ecosystems literatures.
Notwithstanding the references to strong social networks in some of the entrepreneurial ecosystems literature there has been limited systematic discussion of networks and they are not a key building block in some models (Spigel 2015). Third, we apply the concept of gender capital (Huppatz 2012, 2014; Ross-Smith and Huppatz 2010) to conceptualize women-only entrepreneurial networks as potential sites of gender capital creation. Fourth, we contribute to discussions of policy development and argue that initiatives to establish women-only networks have been ineffective: rather than generating gender capital in these networks, women have been placed in ghettos where due to an inability to access sufficient economic, social, cultural and symbolic capital their credibility as entrepreneurs is impeded.

The paper is structured as follows: In the following section, we examine the entrepreneurial ecosystem construct, as the localized operation of complex entrepreneurial processes, and suggest that it can be analysed in terms of Bourdieu's socio-analysis as field, habitus and capital. In the next section, we develop the notion of gender capital as the gender advantage that is derived from a skill set associated with femininity or from simply being recognized as feminine (Ross-Smith and Huppatz 2010). This is a feminist extension and elaboration of Bourdieu's concept of capital that we apply to the development of women's entrepreneurial networks as an intended gender capital enhancing initiative. We then present our research design including the data collection and analysis protocols used. Drawing on data from in-depth, qualitative interviews with network coordinators and women entrepreneurs, we summarise and reflect on the extent to which formally established women-only networks generate gender capital for their members improving their ability to participate in the entrepreneurial ecosystem. The paper concludes by drawing out the implications of our analysis for theory, entrepreneurial practice and economic development policy.

\section{The entrepreneurial ecosystem as a field}

Conventional wisdom suggests that the entrepreneurial ecosystems' literature is only 5 years old (Stam 2015). However, the concept, if not the exact name, has demonstrable antecedents in the industrial clusters, innovation systems and learning regions literatures (Spigel 
and Harrison 2017). All are based on the argument that economic development is a result of the localized operation of complex entrepreneurial processes, and that not all regional economies will have entrepreneurial ecosystems that function at the same level. Much of the contemporary interest in entrepreneurial ecosystems is practice-led, not theory-driven and lacks a commonly agreed definition and characterization. As a result, there is considerable diversity in the number and type of elements identified as core to the construct (Spigel 2015; Stam 2015).

This suggests that, as currently used, the concept's flexibility may be less of a strength and more a chaotic conception, which 'arbitrarily divides the indivisible and/or lumps together the unrelated and the inessential' (Sayer 1992, p. 138). The construct of the 'entrepreneurial ecosystem' as commonly used shows many of the characteristics of a chaotic conception. First, its usage is tautological, in that entrepreneurial ecosystems are defined as those demonstrating successful entrepreneurship, and where successful entrepreneurship is apparent there is deemed to be a strong entrepreneurial ecosystem. Second, it presents a list of factors and characteristics with no reasoning of cause and effect or of how they cohere. Third, there is confusion over the appropriate level of analysis, whether at city, region or nation or as some non-spatial unit such as the corporation, sector or global production system (Stam 2015). The complex category of the 'entrepreneurial ecosystem' has three distinctive aspects: first, the role of (social) context in allowing and restricting entrepreneurship (Welter 2011); second, the influence of the external business environment on the entrepreneur rather than the enterprise (Spigel 2015) and third, the role of entrepreneurs in creating, maintaining and developing the ecosystem and not just responding to its pressures and opportunities (Spigel and Harrison 2017).

It is on this basis that we identify the entrepreneurial ecosystem as a field in Bourdieu's terms. At the core of Bourdieu's (2005) theory of embodied practice are the three closely interrelated concepts of field (a social arena in which people manoeuvre and struggle in pursuit of desirable resources), habitus (dispositions: lasting acquired schemes of perception, thought and action) and capital (the resources acquired (or not) in developing habitus) (Fig. 1). For Bourdieu, fields are arenas for strategic decision-making in which interactions, transactions and events take place and actors struggle and/or succeed by agreeing to follow 'the rules of the game'
(Bourdieu and Wacquant 1992). As actors learn the rules of the game by participating in the field, they develop a sense of the field and their position in it. This habitus comprises the socialised norms and tendencies that guide actors' thinking and behaviour.

Access to and acquisition of capital motivates the practice of actors in the field and underpins the field's structuring principles and relations, not least because the value of capital conferred leads to different hierarchies. For Bourdieu, capital takes a number of forms, and actors can compete for economic capital as well as the more intangible, non-financial social and cultural capital. As defined by Bourdieu (1986) economic capital refers to sums of money or assets put to productive use. Social capital is accrued through networks of influence or support based on group membership (family, social and professional networks). Cultural capital is closely related to economic capital (it takes time and resources to accrue) and can be embodied in an actor through speech, behaviour and dress; objectified through books and artistic objects and institutionalised in the form of educational qualifications. Each of these types of capital can take on the role of symbolic capital, the form that capital takes when it is misrecognised not as capital but as an innate property of an actor, socially legitimized as power, influence, prestige and honour (Tatli et al. 2014; Terjesen and Elam 2009).

In examining women entrepreneurs' participation in formal networks, we focus on socialized and contextualized actors and their specific habitus, including their dispositions of how 'to be and to do' (how to think and how to act) as entrepreneurs. These are acquired through their relationship to the field and the incorporation of its particular logic (Bourdieu 2007):

The specific habitus, which is demanded of the new entrants [to the field] as a condition of entry, is nothing other than a specific mode of thought ... In reality what the new entrant must bring to the game is not the habitus that is tacitly or explicitly demanded there, but a habitus that is practically compatible or sufficiently close, and above all malleable and capable of being converted into the required habitus (Bourdieu 2006, p. 99-100).

Our interest is in how actors are obliged to acquire the sens practique to function in an entrepreneurial ecosystem, how they learn to play the rules of the game (that is, the narratives and justifications of value in the 
Fig. 1 Bourdieu's theory of embodied practice
Habitus manifests the structure of the field and capital determines the position. The field mediates between habitus and practice in the formation and expression of self around an internalised and usually accurate sense of social destiny. field - social arena in which

people manoeuvre for

position and resources

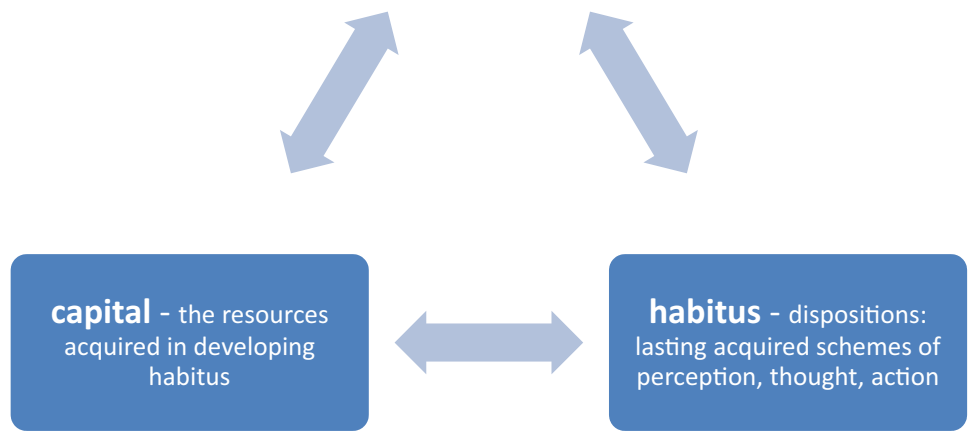

field) and how economic behaviour socially recognized as rational arises out of practice (Bourdieu 2005). The entrepreneurial ecosystems literature highlights how this might be effected through, for example, mentoring, role models, networking and socialization events, both selfgenerated and institutionally provided. We focus on one such initiative, the creation of women-only entrepreneurial networks as an instrument of regional entrepreneurship policy.

\section{Networks and gender capital in entrepreneurial ecosystems}

\subsection{Networks}

The nature of the networks in which entrepreneurs are embedded, the positions they occupy and the patterns of their relationships in them influences their access to significant others and to the resources they need. Networks can be either formal or informal (Ibarra 1992). Formal networks can be more beneficial to their members than informal ones because they are more likely to include more weak ties and structural holes (Watson 2011). Informal networks primarily comprise business contacts, family and personal relationships. Formal networks include professional relationships with accountants, banks, lawyers and trade associations (Littunen
2000), and are formal arrangements between independent businesses to enhance the success of their members and promote regional economic development (Besser and Miller 2011). We focus on those networks established by economic development agencies to stimulate networking and hence entrepreneurial activity, and examine the process and perceived outcomes of belonging to a network, that is 'the actual behaviour of people developing, entering, maintaining, altering and leaving social networks' (Benschop 2009, 221).

Gender affects social capital accumulation (Palgi and Moore 2004), women have less social capital than men (Eagly and Carli 2007) and women in networks face a credibility problem in that they do not or cannot invest in building their own social capital - they 'don't play the game' (Burt 1998). From a social exchange theory perspective (Thibaut and Kelley 1959), men in networks view women as less attractive exchange partners than other men. As effective networking is based on reciprocity, helping now to get help in the future (Kaplan 1984), women are systemically disadvantaged. Furthermore, there is some evidence to suggest that, at least in terms of informal networks, women's networks comprise mainly women and men's men: in male dominated networks, women have less legitimacy and influence and therefore benefit less from participation (Moore 1988). Collectively, these features confirm that women are neither numerous enough nor have access to enough 
economic, cultural, social and symbolic capital to force a redefinition of the requirements of the field (Corson and Costen 2001). It is in view of this that attention has shifted to the concept of gender capital.

\subsection{Gender capital}

For Bourdieu, capital is a resource that defines how opportunities are enabled or constrained for individuals in a given field. Some feminist scholars have suggested broadening Bourdieu's notion of capital to include gender as embodied cultural capital (McCall 1992; Illouz 1997; Lovell 2000; Reay 1997; 2004; Skeggs 2004). They draw on Bourdieu's (1986) argument that embodied cultural capital takes the form of long-lasting dispositions of the mind and body possessed through, for example, processes of self-improvement or socialisation, to assert that gendered dispositions may also act as capital. If gender is cultural capital, then femininity is culturally learned. Consequently, gender capital is a capital that is available to men and women (Huppatz and Goodwin 2013). It comprises the 'knowledge, resources and aspects of identity available - within a given context- that permit access to regimespecific gendered identities' (Bridges 2009, p. 92). Much of it is, however, context specific and individuals employ different aspects of self in different settings to negotiate differently gendered identities: 'gender capital attempts to foreground the independent effect of context on the relative valuations of gendered presentations of self' (Bridges 2009, 92). Gender capital may empower women and provide them with a form of agency to develop and sustain their careers (Huppatz 2009). It can be used by women who have acquired position in a field as a form of agency to disrupt it. In certain situations, these women draw on their feminine dispositions to navigate the boundaries of a field established by men (Ross-Smith and Huppatz 2010). In the case of the entrepreneurial ecosystem women can draw on these dispositions to negotiate its boundaries and cause disruption. However, the outcomes in practice, as we will show below, are not transformative. They do not challenge the power regimes that dominate the field but merely 'tweak at the edges' in ways that are tactical rather than strategic (Skeggs 1997). Gender capital does not compensate for women's insufficient economic, political, social and symbolic capital to 'force a redefinition of the implicit - that is White male - requirements of the field' (Corson and Costen 2001, 18). This has important implications for women's networking as women have less social capital than men and face problems in accumulating it, due to credibility issues in networks preventing them from 'playing the game'. Accordingly, we question the conceptualization of women-only entrepreneurial networks as sites of gender capital creation and accumulation designed to empower women and provide them with agency to disrupt the status quo in entrepreneurial ecosystems.

Women-only entrepreneurial networks have been established to provide opportunities for participants to talk to other women, to reduce their sense of isolation, to enhance their gender capital (and their confidence in it) and to increase their field positions and thus their credibility. As such, they represent an effort to address the practices of symbolic domination, a multifaceted process in which subordinate groups become socialized in 'ideological meanings and values that legitimate prevailing status hierarchies and naturalize the ... privileges of those who occupy dominant positions in the socioeconomic hierarchy' (Üstüner and Thompson 2012, 802; Bourdieu and Wacquant 1992). For Bourdieu (1990), a necessary precondition for the practice of symbolic domination is that members of a subordinated group - for example, women entrepreneurs - believe that their lifestyle practices are inherently inferior to those of the dominant agents in the field. The extent to which networks address this and support women as agents to access and adopt powerful positions in the entrepreneurial ecosystems field, in the eyes of both network coordinators and women entrepreneurs, is addressed in the remainder of the paper.

\section{Research design and process}

\subsection{Research design}

Methodologically, we have adopted a gender-aware perspective that challenges the notion of female essentialism and assumptions of shared subordination (Sprague 2016) In shifting attention away from a 'gender as variable' approach, underpinned by an individualistic focus and objectivist epistemology in which malefemale comparisons dominate, to one in which external social and contextual influences are emphasized, this enables interrogations of how social orders are gendered and the mechanisms by which this gendering is reconstructed. This is consistent with a standpoint feminist 
epistemology (Haraway 1998), employing in-depth interviews to reveal and illuminate the meaning of entrepreneurship through women's experiences, giving 'voice' to these as intrinsically worthy of attention in their own right. By employing in-depth interviews, we encouraged participants to provide detailed accounts of their own experiences in what are essentially 'guided' conversations (Rubin and Rubin 2005) as we sought to discover how they described and structured their world.

\subsection{Research site and context}

This study was undertaken in a peripheral European region where entrepreneurship in general, and female entrepreneurship in particular, is low (Hart et al. 2013). In the early $2000 \mathrm{~s}$, a new entrepreneurship strategy was initiated by the regional development agency. As part of this, an increase in the number of women engaging in entrepreneurship was specifically targeted through initiatives aimed at improving not only the low levels of entrepreneurial activity but also the quality of start-ups by women. Specifically, the development of formal, women-only business networks to promote networking and to offer support to those starting their own ventures was actively encouraged (Invest NI 2003).

\subsection{Sampling and data collection}

Data were collected from a purposive sample comprising the coordinators of women-only networks $(n=6)$ and mixed networks $(n=5)$ and 17 women entrepreneurs: nascent entrepreneurs in business for under 3 years $(n=8)$, and more experienced entrepreneurs in business for 3 years or more $(n=9)$ (see Appendix Table 2). In the absence of an opportunity to conduct a real-time longitudinal study (Benschop 2009), we chose to use these two categories to explore if women's knowledge and understanding of the rules of the game and their behavior changed as a result of being engaged in the field for longer. We used a topic guide in the interviews both to cover the themes to be explored while remaining flexible enough to allow unanticipated issues to emerge and to encourage participants to provide detailed accounts of their own experiences. Preliminary themes which we explored with the women entrepreneurs included their motivations for participating in formal business networks, women-only, mixed-gender or both; their expectations and experiences of participation; their behaviours, especially regarding the initiation, development and maintenance of contacts and relationships; and the potential and actual benefits which they perceived to accrue from network participation, and whether or not these differ in relation to women-only and mixed-gender networks. With the network organisers, we aimed to ascertain their understanding as to why the network had been established; its aims and objectives and if these had been met; its structure and relationships with other networks; target membership; services provided for the network members; and their perception of potential and actual benefits of gained by their members. Each interview lasted up to $2 \mathrm{~h}$ and with permission were tape-recorded and transcribed, producing rich narratives which were interrogated to develop greater understanding of how women interpreted and negotiated their way around the entrepreneurial ecosystem and learnt to play the rules of the game.

\subsection{Data analysis}

We adopted a reflexive critical methodology that specifically challenges the normative (Stead and Hamilton 2018), focuses on the context in which the micropractices of everyday life are embedded (Alvesson and Deetz 2000) and foregrounds the relationship between those who are dominant and those who are not (Calàs et al. 2009). The data analysis process (Table 1) was a recursive rather than a linear process, and the resulting theoretical dimensions (Corley and Gioia 2004; Maitlis and Lawrence 2007) were then used to structure the discussion of the findings.

\section{Findings}

We have structured the presentation of the findings according to three themes identified from the literature review, each of which is discussed in detail and illustrated with fragments of the narrative. In representing the data, we use direct quotes to exemplify the perceptions and experiences of the participants or to highlight or illustrate a particular finding (Marshall and Rossman 1995).

\subsection{Entrepreneurial ecosystem}

The emergence of initiatives to address the underrepresentation of women in entrepreneurial ecosystems, such as institutionally provided networks whose aim is to 
Table 1 Data analysis process

\begin{tabular}{ll}
\hline $\begin{array}{c}\text { Stage } \\
\text { Process of } \\
\text { analysis }\end{array}$ \\
\hline 1 & $\begin{array}{l}\text { Familiarization } \\
\text { with data and } \\
\text { initial insight } \\
\text { into data }\end{array}$
\end{tabular}

2 Immersion

3

Categorization $\begin{gathered}\text { Identification } \\ \text { of key } \\ \text { themes }\end{gathered}$

4

$\begin{array}{cl}\begin{array}{c}\text { Association and } \\ \text { pattern }\end{array} & \begin{array}{c}\text { Constant } \\ \text { recognition }\end{array} \\ & \text { sompari- } \\ & \text { analysis }\end{array}$
analysis

Read for
content

Description of analysis

Comprehend
and
manage
data

The first stage involved reading and then re-reading to familiarize content ourselves with the material.

The second stage involved the identification of broad categories of themes through a process of open-coding. Each transcript was then coded, which resulted in relevant segments of text being highlighted and then organized into relevant clusters.

In the third stage, emergent themes were developed in order to develop tentative links between the transcripts in terms of Bourdieu's theory of practice

Next, we integrated related data drawn from the different transcripts from entrepreneurs and network managers. This involved taking one piece of data and comparing it with all the others that might be similar or different to develop conceptualizations of the possible relations between various pieces of data.
Table 1 (continued)

\begin{tabular}{|c|c|c|c|}
\hline Stage & $\begin{array}{l}\text { Process of } \\
\text { analysis }\end{array}$ & $\begin{array}{l}\text { Level of } \\
\text { analysis }\end{array}$ & $\begin{array}{l}\text { Description of } \\
\text { analysis }\end{array}$ \\
\hline 6 & $\begin{array}{c}\text { Explanation and } \\
\text { abstraction }\end{array}$ & $\begin{array}{l}\text { Contribution } \\
\text { to theory } \\
\text { develop- } \\
\text { ment }\end{array}$ & $\begin{array}{l}\text { ecosystem, network } \\
\text { dynamics and } \\
\text { gender capital. The } \\
\text { subsequent } \\
\text { outcomes identified } \\
\text { the core meaning of } \\
\text { the data, remaining } \\
\text { faithful to the } \\
\text { perspectives of the } \\
\text { respondents, but } \\
\text { within wider social } \\
\text { and theoretical } \\
\text { constructs (Shaw } \\
\text { 1999). } \\
\text { The final stage } \\
\text { involved } \\
\text { re-contextualizing, } \\
\text { or putting the new } \\
\text { knowledge about } \\
\text { the phenomena and } \\
\text { relations back into } \\
\text { the context of how } \\
\text { others have } \\
\text { articulated the } \\
\text { evolving } \\
\text { knowledge. This } \\
\text { process also } \\
\text { identified new } \\
\text { research avenues } \\
\text { and potentially } \\
\text { interesting topics } \\
\text { for further inquiry. }\end{array}$ \\
\hline
\end{tabular}

support the acquisition of a particular entrepreneurial logic (Spigel 2015), was highlighted by the coordinators of the women-only networks; 'we aim to support women going into business and that's our strategy to this day essentially' (W4) and 'to help women develop business opportunities to break down barriers' (W2). However, the coordinators of the mixed networks considered themselves as facilitators between agents in different field positions in the entrepreneurial ecosystem; 'One of my roles, is basically to take them by the hand and introduce them to someone key' (M1) and 'I try to position people with others who are able to help them-important players' (M6). The disparity between the different roles played by the coordinators was summed up by B6: 'I've seen a couple of opportunities where (women-only network) could have been brokered'. As well as brokering opportunities, the coordinators of the mixed networks observed the exercise of 
personalized agency: 'recognition, status, and networking..., it's the status and access to others, access to decision makers' (M4), which was reinforced by the entrepreneurs: 'I joined (mixed network) as I knew it would have the movers and shakers (R9)'. This illustrates that entrepreneurial activity in ecosystems is a function of interdependencies between players and their respective field positions (Stam 2015). An important aspect of this is for agents to determine who occupies the key field positions. This was most evident among members of the mixed networks; 'you know who's the head, who's the committee, who's the proactive people so you are aware of them' (R5) and 'you have all these old members who know each other - it's like starting a new school, you have to negotiate who you are and who they are' (R3).

One of the unique challenges facing women as they launch businesses is the patriarchal nature of the entrepreneurship domain. The lack of fit between women's ascribed femininity and the embedded masculinity of entrepreneurship was acknowledged by the women entrepreneurs: 'entrepreneurship is still a man's world' (B5), 'it is very much a man's environment ... and you have to break into that and as a woman it's very much pushing your way through' (R1). Also evident was the way in which the entrepreneurs obtained a thorough understanding of the habitus, which allowed them to take the appropriate action in any given situation. In our research, the more established entrepreneurs had a greater sense of how to play the game with members of mixed networks having an even more developed understanding. For instance, the coordinators of mixed networks noted 'they're much keener to learn because they feel it's a man's world' (M5); 'It's a massive game and ... it's predominately controlled by men and you have to think and learn how to think like men' (R4); 'So you have to go into a mixed group basically to learn how to play the game' (R2). It appears that the women in the mixed networks deliberately sought to imitate the practices of men to increase their own field positions.

\subsection{Entrepreneurial networks}

The formal networks were social arenas, in which women entrepreneurs could become acculturated into the field and learn its values, rules and dynamics, and also acted as a legitimizing device (Stuart et al. 1999). This was apparent particularly in the mixed networks, 'the network has a credible name, in terms of improving the profile of a small business' (M1). From the entrepreneurs' perspective 'an awful lot of my business is about credibility... I need to be part of [mixed group]' (R2). Despite the overall aim of women-only networks being to increase women's engagement with entrepreneurship, their coordinators observed, 'it is not really about their businesses. These are more support groups...' (W1) and 'they're all very busy ladies, and I think they see the network as a good opportunity to sit down for a bit of a chat and a bit of a catch-up...'(W6). Unsurprisingly, the women-only networks appeared to be associated with negative connotations: "I know friends of mine refer to it (the network) as 'your WI meeting' (R5) or 'The women's network, it sounds a bit WI doesn't it...?'” (B7) . For some women, 'we don't want to get tagged with belonging to XXX (women-only group), we want to belong to YYY (mixed, more established group)' (B2), highlighting that being part of a particular gender grouping can actually reduce legitimacy and the accrual of symbolic capital (Feng 2015).

For our participants 'women-only networks are a stepping stone [to mixed groups]' (R9), which is supported by the coordinators of mixed networks 'once they become established and more confident they need to be in a mixed group to be dealing with men...' (M2) and by the coordinators of the women-only networks, 'We always encourage our women to use (women-only network) as a way of spring boarding themselves into other networks such as (mixed network)' (W1). This suggests a hierarchy of networks, with the women-only networks positioned lower, with a greater emphasis on social capital accumulation, and the mixed networks positioned higher, having a more strategic orientation including interaction with the key players in the entrepreneurial ecosystem.

Women's networking tends to be centred at the intersection of work, family and social life (Ibarra 1992; Foss 2010). Thus, women can be disadvantaged due to their domestic responsibilities and lack of engagement with male oriented networking activities which often exclude women: 'women can easily eliminate themselves from business opportunities as they tend to rush off home to family afterwards, while men retire to the bar which is where a lot of the main networking is conducted' (M6). The entrepreneurs also referred to their inability to penetrate the 'old boys club': 'I've been annoyed that other businesses have got bigger because they play golf ...I just have to accept that the way it is in this particular 
network' (R8) and 'They go golfing every Saturday and rugby matches on Friday and the pub - that's where's all the networking is done....women don't get the chance or the opportunity' (R3).

\subsection{Gender capital and capital conversion}

Network membership alone is insufficient for capital acquisition and conversion; indeed the women had to engage in 'gamesmanship' to stimulate capital conversion. However, as the coordinator of a mixed network observed, 'women's contribution in networks is very interesting - they are part of networks, but don't necessarily contribute...' (M4). This was reinforced by participants of the women-only networks: 'it wouldn't occur to me to be going searching for sales' (R6); 'I suppose my answer should be I'm in it for lots of sales but I'm there for a bit of craic (enjoyment)' (R9). These sentiments were supported by observations from the network coordinators: 'women haven't got the same push as men' (W3) and they 'need to be more business focused rather than relations focused' (W5). Given our focus on how individuals do gender, we are highlighting entrepreneurs' subjectivities and perceptions in this analysis. In the network coordinators' responses (in terms of what they think men do and women do), we see their expectations, considerations and perceptions about what men and women do, not their subjectivities. In many respects the coordinators' responses are more stereotypical than the women's and are extremely essentialist in that they perceive that women do not have the same push or ambition. As potential boundary-spanning players in the field and sources of legitimacy for their members, network coordinators' subjective understanding of their role and positioning within the field remains an important avenue for further research.

Other constraints on capital conversion reflected common assumptions underpinning the association of particular network characteristics with men and women in comparison with each other (Foss 2010). Members of the women-only networks appeared less strategic in their networking activities 'I find the women's network quite relaxed, there's no pressure' (R5). On the other hand, in mixed networks 'its business - men are very much hunters - hunting out business' (R4). Although women-only members may not regard their networks as a place to develop business, they certainly saw their importance in the accrual of social capital: 'I think when you are in business on your own it is reassuring to talk to other people...because you do get a bit isolated' (R7), and 'it's just a relief to talk to other women. The women only thing, I suppose it like being part of a sisterhood type of thing' (B4). However, due to their more enhanced habitus, the more established women entrepreneurs and those in mixed networks were frustrated with social capital accrual only: 'A sense of not being taken seriously if you are not going there to sell' (R9).

Despite being willing to engage in 'gamesmanship', our research revealed that gender, specifically female gender, has a particular influence on capital accumulation and subsequent conversion. This was moderated by the hegemonic masculinity associated with entrepreneurship, which promotes the leading and dominant social positions of men and masculine scripts of behaviours. Even the venue of the mixed networks reinforced the hierarchical gender order: 'The very fact that they have it held in the Reform Club, puts a very different spin on it' (R5). Indeed, androcentrism was evident with the masculinised form of habitus, associated with male gender capital, more readily converted into the symbolic capital associated with entrepreneurship: 'Because a man is taken more seriously when it comes to entrepreneurship and that's all there is to it!' (B8) and '...there is no overt sexism but a sense of not getting taken seriously but because I am woman I must be there for a bit of craic' (R8). Women themselves played a role in reinforcing this hierarchical gender order: 'A lot of people would automatically assume because he's a man he would know more and a lot of women do women a disservice by taking that approach as well' (R3).

Due to the disparity between women's ascribed femininity and the masculine ethos underpinning entrepreneurial ecosystems the women tended to want to blend in with the dominant position. This was particularly evident amongst the more established and mixednetwork members, reflecting their more established habitus. However, it was also recognized that in trying to blend in with the (male) dominant order, women stood out from their ascribed social grouping: 'There would be one or two women with a male mentality and who do business like a man and they are unpopular in the female world but respected in the male world and very, very successful because they are ruthless and can be single minded but they don't help women' (R4). Others felt that being visible as a result of their femininity was advantageous: 'I find that there are advantages in being a woman. [A] guy will always introduce you to other people and I think some women aren't as good at that; 
maybe it's a bit territorial as well' (R2). This demonstrates that the masculine biases embedded in the entrepreneurial ecosystem discourse means that ascribed characteristics like gender inherently shape how capital is accumulated and converted.

\section{Discussion}

Place-based theories of entrepreneurship and innovation emphasize the role of dense social networks and their key actors, including mentors and network creators and brokers. The emerging entrepreneurial ecosystems literature similarly emphasizes the role of social networks as a key component in a functioning ecosystem (Spigel 2015), membership of which conveys legitimacy (De Clercq and Voronov 2009) and access to resources. However, these networks are deeply embedded in wider social, political and economic contexts and power relations and access to them is not homogeneous. Some entrepreneurs or would-be entrepreneurs may have difficulty in accessing the ecosystem on the basis of, for example, gender, age, ethnicity or disability, compromising their ability to gain a thorough understanding the rules of the game. In essence, this habitus represents the legitimation of entrepreneurs and their participation in the ecosystem: as players they know the right action to take in any given situation. As our findings demonstrate, awareness of habitus was not universal but varied systematically. Established women entrepreneurs (with stronger positions in social networks) and members of mixed networks (with the greater legitimacy that conferred) exhibited a greater sense of how to play the game than nascent entrepreneurs and members of women-only networks. Their sense of habitus was more developed and so they felt obliged to learn the field rules to be considered credible players able to function in the entrepreneurial ecosystem. These female entrepreneurs demonstrated a willingness to fit in and were 'malleable and capable of being converted into the required habitus' (Bourdieu 2006, 99-100). Thus, the field's power dynamics placed the onus on the women to fit in and to learn its rules of engagement, rather than to challenge them (Ahl and Marlow 2012).

For nascent entrepreneurs and members of womenonly networks the situation was different. Here, network membership appears to reinforce marginalization and the lack of legitimacy. As part of an entrepreneurial ecosystem's infrastructure, women-only networks may provide access to (women) peer mentors and role models and offer opportunities for mutual support and confidence building, as a crucible for entrepreneurial identity formation (Harrison et al. 2016). However, this is insufficient to develop habitus. If established women entrepreneurs and members of mixed networks, in learning and conforming to, rather than challenging, the field rules remain marginalized in a masculinist ecosystem environment, nascent entrepreneurs and members of women-only networks are doubly marginalized in neither learning and playing by the field rules nor building legitimacy outside their networks.

This analysis has implications for our understanding of the process by which women acquire or do not acquire capital in entrepreneurial ecosystems. To date, cultural capital has received limited attention in the entrepreneurship literature, despite its strong connections to the generation of economic capital and as a source of legitimacy (Pret et al. 2015). We contribute to this literature in identifying gender capital, a form of embodied cultural capital, as an extension of Bourdieu's theory of capital. Further, we have demonstrated aspects of the way in which gender capital as feminine skills and feminine appearance and sexuality may influence women's participation in entrepreneurial ecosystems. For Bourdieu ((1986), 47-49) embodied cultural capital takes the form of long-lasting dispositions of the mind and body and may be possessed through processes of 'self-improvement' or socialization. Much of the gender capital literature, as suggested above, emphasizes its agentic potential in helping women negotiate the boundaries of the field.

This interpretation, however, is tempered by recognizing that gender is an elusive force in social space (McCall 1992). While the structures of gender normalcy in society offer a limited form of capital for girls, through institutionalization as symbolic capital they provide masculine power for boys (Skeggs 1997, 2004). Debating how to address these structures raises the danger of false equivalency and care needs to be taken not to hurt the prospect of equality for women. Celebrating the feminine itself is not enough to adequately negate male privilege and preferencing of the masculine in society. Until society values the feminine on a par with the masculine, girls and women will remain disadvantaged in business, industry, politics and entrepreneurship. Even though gender may be 'an asymmetrical form of capital' (Huppatz and Goodwin 2013, 295), as embodied cultural capital it offers the 
possibility of bridging the agency-structure divide (Fig. 2), a long-standing concern to researchers in small business and entrepreneurship research (Gorton 2000).

Cultural capital comprises cultural artefacts, an objectified state existing in reproductions of the cultural creations of society; institutions, which structure and reproduce a community's way of life; and embodied capital, in the form of durable dispositions in the mind and body (Bourdieu 1986). As a bridge between agency and structure, cultural capital recognizes that structures-families, classes, gender, ethnicity, institutions, networks and the gene pool-impact on individuals, and individuals have certain preferences, resources, sentiments and personalities which in turn impact on their contribution to society. If gender is a distinct form of cultural capital, it helps explain how gender inequality and privilege operate and potentially provides a basis for empowering women, giving them a sense of agency with the capacity to disrupt the field. Specifically, this perspective moves beyond the dichotomization of choice and force in accounting for gendered segregation in entrepreneurial practice. The agency of entrepreneurs, women and men, is a 'complex interaction of habitus, resources and social spaces' and gendered entrepreneurial segregation is 'the result of choices that occur within gendered and classed limits' (Huppatz and Goodwin 2013, 305).

Our findings also have implications for the wider influence of gender on capital accumulation and conversion. Gender capital is convertible and can be used to acquire social capital and economic capital. However, this acquisition may be moderated by the hegemonic masculinity, which takes different shapes in different fields (Bridges 2009). By exploring gender capital as a framework for future research in entrepreneurship, we expose the prevailing theoretical duality of a liberating emancipatory agenda of formalized women-only networks that simultaneously co-exist in the context of institutional constraints regarding who or what is recognized as an entrepreneurial actor in the entrepreneurial ecosystem (McRobbie 2009; Rindova et al. 2009). Relatively little work has focused on unpicking the 'layers of ideological obscuration' (Martin 1990, 343) which surround women-only networks, elevating them to a panacea solution to contemporary socio economic problems. Although negative female gender capital can be countered by amassing other types of capital (DjerfPierre 2005) including symbolic capital, our study suggests otherwise. Membership of women-only networks conjured up negative connotations such as 'knitting circles and women's groups', with a detrimental impact on the accrual of symbolic capital and the building of legitimacy.

Our findings indicate that more research is required on the social psychology of entrepreneurship in a Bourdieusian framework of fields, habitus and dispositions. First, as this study is based on the lived experiences of a particular group of women entrepreneurs in a particular context at a particular point in time, there is a need for replication studies in other contexts. Second, as

Fig. 2 Agency and structure and the bridging role of cultural capital (adapted from O'Hara 2008)

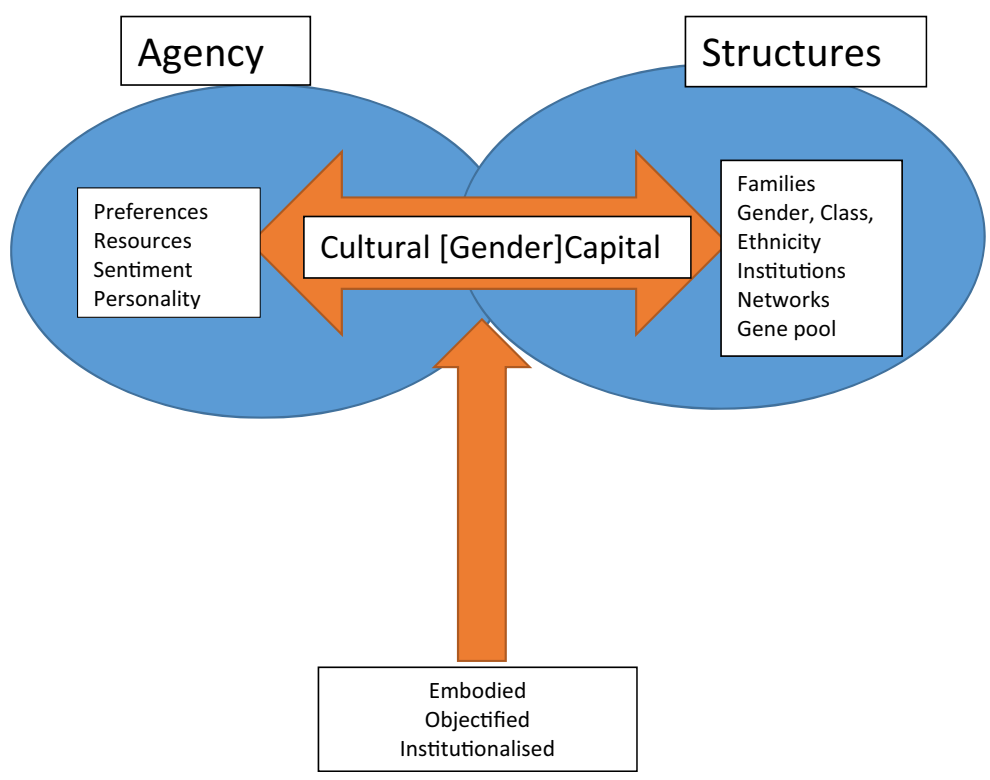


a cross-sectional snapshot of field, habitus and capital this research needs to be complemented by studies that address the dynamics of how women's field position has evolved or could evolve, which is important for the development of effective policies. Third, while we have identified the role of glass ceilings, glass walls and maternal walls in shaping women's economic positioning, additional work could explore how to integrate this into a post-Bourdieusian framework. Fourth, our research on the subjectivities of women's experiences as network members should be matched by a similar analysis of the subjective understandings that network coordinators have of their boundary spanning role in the field. Fifth, gender capital is not restricted to women and exploring all dimensions-male/ masculine and female/ feminine - will provide a more holistic understanding of the entrepreneurial process. Sixth, this will support a deeper analysis of the manner in which ascribed characteristics, such as gender, inherently shape how capital is accumulated and converted in entrepreneurial ecosystems. Seventh, further exploration of the concept of gender capital in advancing debate over the efficacy and emancipatory potential of women-only networks in the face of the masculinized bias informing the foundations of entrepreneurial discourse, is required also (Calàs et al. 2009). Finally, our analysis and discussion touches on, but does not resolve, the tensions that run through feminist post-Bourdieusian theorizing as a whole, between liberal feminism and radical feminism, particularly as they relate to policy prescriptions. These tensions will have to be addressed in future appropriations of post-Bourdieusian scholarship in entrepreneurship.

\section{Conclusion}

Our aim in this research was to investigate the extent to which formal women-only networks established by policy initiatives improved women's access to and participation in entrepreneurial ecosystems. However, we argue that, as currently conceptualized, the entrepreneurial ecosystem is a chaotic conception that describes rather than explains to a more complex category underpinned by analytical rigor (Sayer 1992). Chaotic conceptions are imbued with meaning that changes with the interests and purposes of those using it, that is, they are abstractions that function actively to carry out real ideological work, disguising interests and inequalities. As such, it is striking that the entrepreneurial ecosystems literature does not engage with contemporary debates about gender. Even though it emphasizes the entrepreneur, this entrepreneur is portrayed as disembodied, sex-less and gender-less in a literature that is as hetero-normative and gender blind as any other body of entrepreneurial discourse.

Through the narratives of the masculinity of entrepreneurship that are co-produced and perpetuated through the actions and behaviours of the participants in, and facilitators of, networks, we have demonstrated that challenges for women still remain in entrepreneurial ecosystems. In this respect, women-only networks, a key policy intervention in a number of jurisdictions (OECD 2004; EU 2015), are particularly problematic. They focus, in Bourdieu's terms, on the accrual of social capital and, to a lesser extent, of some cultural capital through training and education. There is less emphasis, however, on acquiring economic capital through the generation of business opportunities. Mixed-network coordinators and participants tended to stress strategic issues over operational ones, and there is some evidence of symbolic capital creation. While network participation appears to be associated with more awareness of the importance for women entrepreneurs to acquire fuller understanding of the entrepreneurial ecosystem and its dynamics, the socialized norms and tendencies that guide thinking and behaviour remain gendered. There is, therefore, little evidence of the established heteronormative orthodoxy being challenged, limited suggestion that gender capital is being developed and only occasional reference to women behaving differently and on their own terms. Indeed, these women-only and mixed networks appear to reinforce the established view that to be successful in the field (the entrepreneurial ecosystem) women have to learn to play according to the dominant rules.

Rather than generating gender capital, entrepreneurs in women-only entrepreneurial networks are in a situation where they are unable to access sufficient economic, social, cultural and symbolic capital, restricting their ability to establish credibility as field players. As a result, their isolation and underrepresentation in the entrepreneurial ecosystem continues. Instead of addressing this problem, as was intended, the creation of formal women-only networks has reinforced and reproduced the embedded masculinity of the entrepreneurship domain. Policy initiatives to establish women-only networks have been largely ineffective. We suggest that 
this policy is re-considered as it is inappropriate to design and introduce initiatives, which do not address deeper structural issues inherent within the entrepreneurial ecosystem. Based on the assumption that the entrepreneurial ecosystem was a level playing field, women-only networks were established to helping women negotiate its boundaries and disrupt the ecosystem. However, instead of being sites of gender capital creation and accumulation to empower women and provide them with agency (Corson and Costen 2001), the networks became ghettos for women, where the other players were women and the stakes were not as high. Accordingly, the dominant field actors (men entrepreneurs) did not deem the networks as credible nor as sites to accrue economic capital. In fact, they served to reproduce the idea that women are a problem to be fixed, perpetuating the binary distinction between men and women (Feng 2015).

Addressing these issues will require a reexamination of both the process and content of policy interventions. In terms of process, our research suggests that separatist women-only solutions have limited efficacy and should be reconsidered; equally, however, non-gendered provision will have to be designed carefully to avoid the perpetuation of men's structural advantage. In terms of content, policy makers will need to focus on addressing the processes underlining the production of capital in the negotiation of status games in entrepreneurial ecosystems: in working with both women and men entrepreneurs to develop effective capital-building, habitus-enhancing and field-positioning strategies, the full expression of the concept of gender capital within a wider understanding of gender fluidity as constructed and negotiated provides a valuable starting point.

Acknowledgements This work was supported by the British Academy [Grant No. SG 47047].

\section{Appendix}

Table 2 Details of respondents

\begin{tabular}{|c|c|c|c|}
\hline $\begin{array}{l}\text { Women entrepreneur } \\
\text { respondents }\end{array}$ & Business owner & $\begin{array}{l}\text { Network } \\
\text { type }\end{array}$ & Business \\
\hline B1 & Nascent & $\begin{array}{c}\text { Women } \\
\text { only }\end{array}$ & Exhibition/conference stand manufacturer \\
\hline $\mathrm{B} 2$ & Nascent & $\begin{array}{l}\text { Women } \\
\text { only }\end{array}$ & $\begin{array}{l}\text { Inward investor facilitator/talent } \\
\text { management }\end{array}$ \\
\hline B3 & Nascent & Mixed & $\begin{array}{l}\text { Training and consultancy - health and } \\
\text { well-being }\end{array}$ \\
\hline B4 & Nascent & Mixed & Life coach \\
\hline B5 & Nascent & Mixed & Event's organizer \\
\hline B6 & Nascent & $\begin{array}{c}\text { Women } \\
\text { only }\end{array}$ & Tea and coffee importer \\
\hline B7 & Nascent & $\begin{array}{c}\text { Women } \\
\text { only }\end{array}$ & Project management \\
\hline B8 & Nascent & Mixed & Life insurance \\
\hline $\mathrm{R} 1$ & Established & $\begin{array}{l}\text { Women } \\
\text { only }\end{array}$ & $\begin{array}{l}\text { Designer-hospitality } \\
\text { and leisure industry }\end{array}$ \\
\hline $\mathrm{R} 2$ & Established & Mixed & Designer-hospitality and leisure industry \\
\hline $\mathrm{R} 3$ & Established & Mixed & Finance \\
\hline R4 & Established & Mixed & Event's organizer \\
\hline R5 & Established & Mixed & Insurance broker \\
\hline R6 & Established & $\begin{array}{c}\text { Women } \\
\text { only }\end{array}$ & Virtual office services \\
\hline R7 & Established & & Beautician (chain of shops) \\
\hline
\end{tabular}


Table 2 (continued)

\begin{tabular}{|c|c|c|}
\hline R8 & Established & $\begin{array}{l}\text { Women } \\
\text { only } \\
\text { Mixed }\end{array}$ \\
\hline Women-only networks & Year of formation & Rationale/purpose/aim \\
\hline W1 & $\begin{array}{l}2002 \text { by } 10 \text { female business women; } \\
\text { Formally established } 2005 \text { - } \\
\text { Board established-funding obtained } \\
\text { funding obtained from local } \\
\text { development agencies }\end{array}$ & $\begin{array}{l}\text { To provide support (help each other, be with like-minded } \\
\text { women), information providers, networking (making } \\
\text { connections) }\end{array}$ \\
\hline W2 & $\begin{array}{l}2001 \\
\text { budget from local development agency } \\
\text { of } £ 5000 \text { to provide Increased business } \\
\text { opportunities }\end{array}$ & Support, develop networking capability \\
\hline W3 & $\begin{array}{l}\text { 1986, formally established } 1996 \text {, } \\
\text { established by group of female } \\
\text { businesswomen and academics; funding from } \\
\text { local development agencies }\end{array}$ & $\begin{array}{l}\text { Information and experience sharing, talk about the 'glass } \\
\text { ceiling', provide training courses }\end{array}$ \\
\hline W4 & $\begin{array}{l}\text { 1989/1999-with funding obtained from } \\
\text { local development agencies }\end{array}$ & $\begin{array}{l}\text { Support women going into business; signposting, } \\
\text { networking, making connections }\end{array}$ \\
\hline W5 & $\begin{array}{l}2004 \text { - with funding obtained from local } \\
\text { development agencies }\end{array}$ & $\begin{array}{l}\text { Support women going into business, share information, } \\
\text { develop business opportunities, break down barriers, } \\
\text { identify role models }\end{array}$ \\
\hline W6 & $\begin{array}{l}\text { 2003/2004 — with funding obtained from } \\
\text { local development agencies }\end{array}$ & Support women \\
\hline Mixed networks & Year of formation & Rationale/purpose/aim \\
\hline M1 & 1974 & $\begin{array}{l}\text { Result of introduction of national insurance (tax) } \\
\text { contributions and impact on small business owners } \\
\text { Campaigning pressure group and lobbying }\end{array}$ \\
\hline M2 & 2003 & $\begin{array}{l}\text { Initiative of local council } \\
\text { Support and develop businesses, helping the economy } \\
\text { and reduce unemployment }\end{array}$ \\
\hline M3 & Early 1990 s & $\begin{array}{l}\text { Geared at manufacturing industry initially in engineering } \\
\text { though in the late } 1990 \text { s it was opened to all industrial } \\
\text { sectors } \\
\text { Forum for industry and university interaction, technology } \\
\text { and knowledge transfer, discuss mutual problems }\end{array}$ \\
\hline M4 & $100+$ years & $\begin{array}{l}\text { Focus on individual membership not company } \\
\text { Represent members, lobby government, provision of } \\
\text { advice }\end{array}$ \\
\hline M5 & Early 1980 s & $\begin{array}{l}\text { Geared at manufacturing industry; aimed at larger orgs, } \\
\text { sharing experiences and best practice }\end{array}$ \\
\hline
\end{tabular}

Open Access This article is distributed under the terms of the Creative Commons Attribution 4.0 International License (http:// creativecommons.org/licenses/by/4.0/), which permits unrestricted use, distribution, and reproduction in any medium, provided you give appropriate credit to the original author(s) and the source, provide a link to the Creative Commons license, and indicate if changes were made.

\section{References}

Ahl, H. (2006). Why research on women entrepreneurs needs new directions. Entrepreneurship Theory and Practice, 30(5), 596-621.

Ahl, H., \& Marlow, S. (2012). Exploring the dynamics of gender, feminisim and entrepreneurship: advancing debate to escape a dead end? Organization, 19(5), 543-562. 
Ahl, H., \& Nelson, T. (2015). How policy positions women entrepreneurs: a comparative analysis of state discourse in Sweden and the United States. Journal of Business Venturing, 30, 273-291.

Alvesson, M., \& Deetz, S. (2000). Doing critical management research. London: Sage Publications.

Benschop, Y. (2009). The micro-politics of gendering in networking. Gender, Work and Organization, 16(2), 217-237.

Besser, T. L., \& Miller, N. (2011). The structural, social and strategic factors associated with successful networks. Entrepreneurship and Regional Development, 23, 113-134.

Bourdieu, P. (1986). The forms of capital. In J. E. Richardson (Ed.), Handbook of Theory and Research for the Sociology of Education, trans. R. Nice. New York: Greenwood Press.

Bourdieu, P. (1990). In J. B. Thompson (Ed.), Language and symbolic power. Cambridge: Harvard University Press.

Bourdieu, P. (2005). The social structures of the economy. Cambridge: Polity.

Bourdieu, P. (2006). Pascalian meditations. Cambridge: Polity.

Bourdieu, P. (2007). In other words. Cambridge: Polity.

Bourdieu, P., \& Wacquant, L. J. D. (1992). An invitation to reflexive sociology. Chicago: University of Chicago Press.

Boyde, E. (2017) Single-sex networks under a spotlight. Financial Times, 8 March (https://www.ft.com/content/3f068f20-de3f11e6-9d7c-be108f1c1dce, accessed 11 Apr. 2017).

Bridges, T. S. (2009). Gender capital and male bodybuilders. Body \& Society, 15, 83-107.

Burt, R. (1998). The gender of social capital. Rationality and Society, 10(5), 5-47.

Calàs, M. B., Smircich, L., \& Bourne, K. A. (2009). Extending the boundaries: reframing "entrepreneurship as social change" through feminist perspectives. Academy of Management Review, 34(3), 552-569.

Corley, K. G., \& Gioia, D. A. (2004). Identity ambiguity and change in the wake of a corporate spin-off. Administrative Science Quarterly, 49, 173-208.

Corson, D., \& Costen, W. (2001). Is the glass ceiling unbreakable? Habitus, fields, and the stalling of women and minorities in management. Journal of Management Inquiry, 10, 16-25.

De Clercq, D., \& Voronov, M. (2009). Toward a practice perspective of entrepreneurship: entrepreneurial legitimacy as habitus. International Small Business Journal, 27, 395-419.

Djerf-Pierre, M. (2005). Lonely at the top: gendered media elites in Sweden. Journalism, 6, 265-290.

Eagly, A. H., \& Carli, L. L. (2007). Through the labyrinth: the truth about how women become leaders. Boston: Harvard Business School Press.

Ely, R. J., \& Meyerson, D. E. (2000). Theories of gender: a new approach to organizational analysis and change. Research in Organizatonal Behaviour, 22, 103-153.

EU (2015) Promoting entrepreneurship: support networks for women. Available at: http://ec.europa. eu/growth/smes/promoting-entrepreneurship/we-workfor/women/support-networks/index_en.htm (last accessed, 31 Dec. 2015).

Feng, L. (2015) Your rolodex matters, but by how much depends on your gender. (http://knowledge.insead.edu/career/yourrolodex-matters-but-by-how-much-depends-on-yourgender-3862\#dhrXj1CeKITM4qq5.99, accessed 11 Apr. 2017).
Foss, L. (2010). Research on entrepreneur networks: the case for a constructionist feminist theory perspective. International Journal of Gender and Entrepreneurship, 2(1), 83-102.

Fritsch, M. (2011). The effect of new business formation on regional development: empirical evidence, interpretation and avenues for further research. In M. Fritsch (Ed.), Handbook of research on entrepreneurship and regional development (pp. 58-106). Cheltenham: Edward Elgar.

Gorton, M. (2000). Overcoming the structure - agency divide in small business research. International Journal of Entrepreneurial Behaviour and Research, 6, 276-292.

Graham, G. (1994). Liberal vs radical feminism revisited. Journal of Applied Philosophy, 11, 155-170.

Haraway, D. (1998). Situated knowledges: the science question in feminism and the privilege of partial perspective. Feminist Studies, 14, 575-599.

Harrison, R., Leitch, C., \& McAdam, M. (2016). Identity work and the development of entrepreneurial leadership: does gender matter? In T. Nelson, K. Lewis, \& C. Henry (Eds.), Global female entrepreneurship handbook. London: Routledge.

Hart, M., Bonner, K. and Levie, J. (2013). Global Entrepreneurship Monitor: Northern Ireland Report 2013. Belfast: Global Entrepreneurship Monitor and Invest NI.

Hewlett, S.A. (2014). What's holding women back in science and technology industries, Harvard Business Review, available at https://hbr.org/2014/03/whats-holding-women-back-inscience-and-technology-industries/, accessed 23 Dec.2015.

Huppatz, K. (2009). Reworking Bourdieu's "Capital": feminine and female capitals in the field of paid caring work. Sociology, 43, 45-66.

Huppatz, K. (2012). Gender capital at work: Intersections of femininity, masculinity, class and occupation. Houndmills: Palgrave Macmillan.

Huppatz, K. (2014). Theories of vertical segregation in feminised occupations: rethinking dominant perspectives and making use of Bourdieu. In A. Broadbridge \& S. Fielden (Eds.), Handbook of gendered careers in management: getting in, getting on, getting out. Cheltenham: Edward Elgar.

Huppatz, K., \& Goodwin, S. (2013). Masculinized jobs, feminized jobs and men's 'gender capital' experiences: understanding occupational segregation in Australia. Journal of Sociology, 49, 291-308.

Ibarra, H. (1992). Personal networks of women and minorities in management. The Academy of Management Review, 18(1), 56-87.

Illouz, E. (1997). Who will take care of the caretaker's daughter? Towards a sociology of happiness in the era of reflexive modernity. Theory, Culture \& Society, 14, 31-66.

Invest NI (2003) Accelerating entrepreneurship strategy: A strategy to increase the levels of entrepreneurial activity in Northern Ireland, http://www.investni.gov.uk accessed 20 Sep 2010.

Kaplan, R. E. (1984). Trade routes: the manager's network of relationships. Organizational Dynamics, 12(4), 37-52.

Littunen, H. (2000). Networks and local environmental characteristics in the survival of new firms. Small Business Economics, 15(1), 59-71.

Lovell, T. (2000). Thinking feminism with and against Bourdieu. Feminist Theory, 1, 11-32. 
Maitlis, S., \& Lawrence, T. B. (2007). Triggers and enablers of sensegiving in organizations. Academy of Management Journal, 50, 57-84.

Marshall, C., \& Rossman, G. B. (1995). Designing qualitative research. London: Sage.

Martin, J. (1990). Organizational taboos: the suppression of gender conflict in organizations. Organization Science, 1(4), 339-359.

McCall, L. (1992). Does gender fit? Bourdieu, feminism, and the concepts of social order. Theory and Society, 21, 837-867.

McRobbie, A. (2009). The aftermath of feminism. London: Sage.

Moore, G. (1988). Women in elite positions: insiders or outsiders? Sociological Forum, 3, 566-585.

Motoyama, Y., Konczal, J., Bell-Masterson, J., \& Morelix, A. (2014). Think locally, act locally: building a robust entrepreneurial ecosystem. Kauffman Foundation.

O'Hara, P. A. (2008). Cultural capital. In W. A. Darity (Ed.), International encyclopedia of the social sciences (pp. 189191). Detroit: Macmillan Reference.

OECD (2004) Women's entrepreneurship: issues and policies. Background Report for 2nd OECD Conference of Ministers Responsible for Small and Medium-sized Enterprises (SMEs): Promoting Entrepreneurship and Innovative SMEs in a Global Economy: Towards a More Responsible and Inclusive Globalisation, Istanbul, Turkey 3-5 June 2004. http://www.oecd.org/cfe/smes/31919215.pdf (accessed 31 December 2015).

Palgi, M., \& Moore, G. (2004). Social capital: Mentors and contacts. Current Sociology, 52, 459-480.

Pret, T., Shaw, E., \& Drakopoulou Dodd, S. (2015). Painting the full picture: the conversion of economic, cultural, social and symbolic capital. International Small Business Journal, 124. https://doi.org/10.1177/0266242615595450.

Reay, D. (1997). Feminist theory, habitus, and social class: Disrupting notions of classlessness. Women's Studies International Forum, 20, 225-233.

Reay, D. (2004). Gendering Bourdieu's concept of capitals? Emotional capital, women and social class. In L. Adkins \& B. Skeggs (Eds.), Feminism after Bourdieu. Oxford: Blackwell.

Rindova, V., Barry, D., \& Ketchen, D. (2009). Entrepreneurship as emancipation. Academy of Management Review, 34(3), 477491.

Ross-Smith, A., \& Huppatz, K. (2010). Management, women and gender capital. Gender, Work and Organization, 17, 547565.

Rubin, H., \& Rubin, I. (2005). Qualitative interviewing: the art of hearing data (2nd ed.). London: Sage.

Sayer, A. (1992). Method in social science: a realist approach. Abingdon: Routledge.

Shaw, I. F. (1999). Qualitative Evaluation. London: Sage Publications.

Skeggs, B. (1997). Formations of class and gender: Becoming respectable. London: Sage.
Skeggs, B. (2004). Context and background: Pierre Bourdieu's analysis of class, gender and sexuality. In L. Adkins \& B. Skeggs (Eds.), Feminism after Bourdieu (pp. 19-34). Oxford: Blackwell.

Spigel, B. (2015). The relational organization of entrepreneurial ecosystems. Entrepreneurship Theory and Practice, Article first published online: 25 June 2015. https://doi.org/10.1111 /etap. 12167.

Spigel, B., \& Harrison, R. T. (2017). Towards a theory of entrepreneurial ecosystems. Strategic Entrepreneurship Journal. https://doi.org/10.1002/sej.1268.

Sprague, J. (2016). Feminist methodologies for critical researchers: bridging differences. Walnut Creek: AltaMira/ Rowman \& Littlefield.

Stam, E. (2015). Entrepreneurial ecosystems and regional policy: a sympathetic critique. European Planning Studies, 23(9), 759-1769.

Stangeler, D., \& Bell-Masterson, J. (2015). Measuring an entrepreneurial ecosystem. Kauffman foundation research series on city, metro and regional entrepreneurship. Kansas City: Kauffman Foundation.

Stead, V., \& Hamilton, E. (2018). Using critical methodologies to examine entrepreneurship. In R. T. Harrison \& C. M. Leitch (Eds.), Handbook on entrepreneurship and leadership (pp.87-105). Cheltenham: Edward Elgar.

Stuart, T. E., Hoang, H., \& Hybels, R. C. (1999). Interorganizational endorsements and the performance of entrepreneurial ventures. Administrative Science Quarterly, 44, 315-349.

Tatli, A., Vassilopoulou, J., Özbiligin, M., Forson, C., \& Slutskaya, N. (2014). A Bourdieuan relational perspective for entrepreneurship research. Journal of Small Business Management, 52(4), 615-632.

Terjesen, S. and Elam, A. B. (2009). Transnational entrepreneurs' venture internationalization strategies: A practice theory approach. Entrepreneurship Theory and Practice, 33(5), 10931120.

Thibaut, J. W., \& Kelley, H. H. (1959). The social psychology of groups. New York: Wiley.

Üstüner, T., \& Thompson, C. J. (2012). How marketplace performances produce interdependent status games and contested forms of symbolic capital. Journal of Consumer Research, $38,796-814$.

Watkins, K. K. (2015). Examining the connections within the startup ecosystem, paper to DIANA International Research Conference, Babson College, MA, 8-9 June.

Watson, J. (2011). Networking: gender differences and the association with firm performance. International Small Business Journal, 30, 536-558.

Welter, F. (2011). Contextualising entrepreneurship: conceptual challenges and ways forward. Entrepreneurship Theory and Practice, 35(1), 165-184. 